\title{
EKSISTENSI KOMISI PENGAWAS PERSAINGAN USAHA DALAM PENANGANAN PERSEKONGKOLAN TENDER DALAM PERSPEKTIF HUKUM POSITIF INDONESIA
}

\author{
Surya Bhakti \\ Prodi Magister Hukum, Fakultas Hukum-Universitas Mataram NTB \\ manshurmih15@gmail.com \\ Zainal Asikin \\ Dosen Fakultas Hukum-Universitas Mataram NTB \\ asikinzainalfh@unram.ac.id \\ Sahnan \\ Dosen Fakultas Hukum-Universitas Mataram NTB \\ sahnan_mih@yahoo.co.id
}

\begin{abstract}
This study aimed to examine and analyze the legal position of the the Supervision Commission as the only institution dealing with competition law in Indonesia legal system and determine the existence of law enforcement of the Commission as the only institution related to tender collusion (conspiracy) viewed from the Indonesian legal perspective. This was a normative study (research), with a statutory and conceptual approach. The results of this study indicated that the position of the Supervision Commission as the only institution dealing with competition law in Indonesia in the justice system was independent from the influence of other institutions in resolving disputes on unfair business competition in Indonesia; and the existence of the Commission is the only institution dealing with competition law in Indonesia in carrying out its duties and authorities in accordance with the mandate of the Law Number 5 of 1999 concerning the prohibition of monopolistic practices and unfair business competition.
\end{abstract}

Keywords: Supervision commission, business competition, tender collusion, positive law

How to Cite: Surya Bhakti, et.al. 2020. Eksistensi Komisi Pengawas Persaingan Usaha dalam Penanganan Persekongkolan Tender dalam Perspektif Hukum Positif Indonesia. 4(1): pp. 38-52. DOI: https://doi.org/ 10.24036/jess/vol4-iss1

\section{Pendahuluan}

Di dalam fenomena persaingan usaha nasional selalu terdapat issue kondisi struktural ekonomi, issue prilaku pro-persaingan atau anti- persaingan. Dalam perspektif hukum terkait dengan masalah persaingan usaha tergantung ada atau tidaknya aturan (code of conduct) dari prilaku tersebut.

Persaingan usaha, menurut (Saliman, 2004), pada dasarnya mengatur mengenai perilaku, tindakan atau perbuatan termasuk perjanjian yang dilarang dilakukan oleh satu atau lebih pelaku usaha dalam menjalankan kegiatan usahanya 
dimana pelanggran atas kaedah tersebut dapat dikenakan sanksi, baik yang bersifat administratif maupun sanksi pidana. Namun, persaingan usaha yang sehat akan berakibat positif bagi para pengusaha yang saling bersaing atau berkompetisi karena dapat menimbulkan upaya-upaya peningkatan efisiensi, produktivitas, dan kualitas produk yang dihasilkan.

Persaingan usaha yang terjadi antara pelaku usaha, penegakan hukumnya diselesaikan melalui mekanisme KPPU (Komisi Pegawas Persaingan Usaha). Terhadap putusan KPPU diberikan kepada pelaku hak untuk mengajukan keberatan ke pengadilan negeri. Selain itu ia dapat pula diserahkan kepada kepolisian, kemudian diteruskan ke pengadilan jika pelaku usaha tidak bersedia menjalankan putusan yang telah dijatuhkan oleh KPPU. Tentunya hal di atas didasarkan oleh ketentuan Peraturan Perundang-Undangan Nomor 5 tahun 1999 tentang Larangan Praktek Monopoli dan Persaingan Usaha Tidak Sehat.

Komisi Pegawas Persaingan Usaha (KPPU) merupakan lembaga baru yang dikenalkan oleh Undang-Undang Nomor 5 tahun 1999. Banyak hal terkait dengan praktek monopoli dan pesaingan usaha tidak sehat diatur dalam undang-undang ini, lebih-lebih persekongkolan tender juga termasuk di dalamnya.

Persekongkolan tender merupakan bentuk kegiatan yang dilarang menurut Undang-Undang Nomor 5 tahun 1999 tentang Larangan Praktek Monopoli dan Persaingan Usaha Tidak Sehat, yang dijelaskan dalam pasal 22, yang berbunyi :

... pelaku usaha dilarang bersekongkol dengan pihak lain untuk mengatur dan atau menentukan pemenang tender sehingga dapat mengakibatkan terjadinya persaingan usaha tidak sehat....

Undang-undang nomor 5 tahun 1999, dalam penjelasan pasal 22, mengatur bahwa yang dimaksud dengan tender adalah tawaran mengajukan harga untuk memborong suatu pekerjaan, untuk mengadakan barang-barang atau untuk menyediakan jasa. Dalam undang-undang tersebut dijelaskan bahwa yang dimaksud dengan barang adalah setiap benda, baik berwujud maupun tidak berwujud, baik bergerak maupun tidak bergerak, yang dapat diperdagangkan, dipakai, dipergunakan, atau dimanfaatkan oleh konsumen atau pelaku usaha.

Persekongkolan tender dilarang karena dapat menimbulkan persaingan usaha tidak sehat dan bertentangan dengan tujuan dilakukannya tender tersebut, yaitu untuk memberikan kesempatan yang sama kepada pelaku usaha agar dapat menawarkan harga dan kualitas bersaing. Dengan adanya larangan ini diharapkan pelaksanaan tender akan menjadi efisien, artinya mendapatkan harga murah dengan kualitas baik (Sumber: Peraturan KPPU Nomor 2 tahun 2010 dan UU No. 5/1999).

Persekongkolan tender merupakan suatu kegiatan yang dilakukan para pelaku usaha dengan cara melakukan kesepakatan-kesepakatan yang bertujuan memenangkan tender. Berdasarkan pengertian yang telah disebutkan dalam pasal 22 Undang-Undang Nomor 5 tahun 1999 tentang Larangan Praktek Monopoli dan Persaingan Usaha Tidak Sehat, maka unsur-unsur dalam persekongkolan tender menurut Krisanto (2008) adalah:

a. Adanya dua atau lebih pelaku usaha,

b. Adanya kerjasama untuk melakukan persekongkolan dalam tender,

c. Adanya tujuan untuk menguasai pasar,

d. Adanya usaha untuk mengatur atau menentukan pemenang tender, dan 
e. Mengakibatkan persaingan usaha tidak sehat.

Namun dalam menganalisis permasalah persekongkolan tender dari unsur-unsur yang telah diuraikan, peneliti menyandingkan dan mencoba membawa persekongkolan tender di kaitkan dengan tindak pidana korupsi yang mengakibatkan kerugian keuangan negara dan penyalahgunaan wewenang penyelenggara negara. Karena, tidak dapat dipungkiri, pengguna jasa lebih di dominasi oleh kalangan pemerintah, dan konsekuensi dari hal tersebut akan mengadakan hubungan hukum yang mengikat satu sama lain yang melibatkan tentunya keuangan pemerintah di dalamnya.

\section{Metode Penelitian}

Jenis penelitian ini adalah penelitian Normatif. Dalam penelitian ini peneliti menitikberatkan pada pertentangan norma dimana kewenangan KPPU dalam penyelesaian tender dalam penyelesaian sengketa secara vertikal disandingkan dengan kewenangan pengadilan tindak pidana korupsi. Pendekatan yang digunakan dalam penelitian ini adalah pendekatan perundang-undangan dan pendekatan konseptual. Jenis bahan hukum yang digunakan adalah bahan hukum primer, bahan hukum sekunder, dan bahan hukum tersier.

Teknik pengumpulan data yang digunakan dalam penelitian ini adalah dengan cara mengumpulkan keseluruhan data yang relevan dengan masalah yang diteliti melalui studi dokumentasi dan data lapangan yang diperoleh dengan tahapan inventarisasi, sistematisasi, sinkronisasi dan harmonisasi berbagai dokumen hukum yang terkait. Analisis data yang digunakan dalam penelitian ini adalah dengan cara mengumpulkan data-data yang didapat dan dianalisis dengan cara deduktif, kemudian analisis secara komperhensif dengan menggunakan bahan hukum yang dijadikan sebagai dasar. Oleh sebab itu analisis bahan hukum yang dilakukan adalah dengan melakukan interpretasi.

\section{Kedudukan Komisi Pengawas Persaingan Usaha (KPPU) dalam Sistem Peradilan}

Lahirnya Undang-Undang No. 5 Tahun 1999 tentang Larangan Praktek Monopoli dan Persaingan Usaha Tidak Sehat (Lembaran Negara RI No.33 Tahun 1999) merupakan pergerakan penting dalam upaya penyehatan perkonomian nasional. Undang-Undang No. 5 Tahun 1999 adalah sebuah refleksi dari semangat pembangunan sistem ekonomi pasar yang efesien, terbuka, dan sehat. Bahkan suatu bangsa yang hendak maju menuju sistem ekonomi dan politik yang modern, perlu meletakkan fondasi sistem hukumnya di bidang ekonomi dalam bentuk peraturan, yang menjaga agar dunia usaha dapat bersaing secara sehat, jujur, dan adil, maka kehadiran institusi hukum ini merupakan suatu syarat mutlak bagi sistem ekonomi yang modern (Margono, 2009).

Rendahnya pengetahuan masyarakat terhadap KPPU terbukti dari hasil persepsi masyarakat terhadap KPPU. Kurangnya kesadaran masyarakat akan pentingnya Undang-undang Nomor 5 tahun 1999 ditanggapi positif oleh KPPU. Realitas tersebut menjadi latar belakang bagi KPPU untuk menyusun strategi guna menyadarkan masyarakat akan arti penting Undang-undang Nomor 5 tahun 1999. 
Sosialisasi dan advokasi terus diupayakan secara maksimal dan berkesinambungan. Informasi mengenai hukum persaingan usaha dan KPPU perlu dikomunikasikan melalui beberapa pendekatan dan strategi komunikasi.

Peningkatan jumlah perkara yang diputus oleh KPPU, pada satu sisi, menunjukkan adanya peningkatan pengetahuan mengenai eksistensi KPPU. Namun di sisi lain juga menunjukkan masih banyaknya praktek persaingan yang tidak sehat terjadi di Indonesia, khususnya dalam tender di sektor pemerintah. Dalam berbagai perkara tender tersebut hampir selalu ditemukan pola persekongkolan yang sama, yaitu melibatkan oknum pihak pemerintah sendiri (persekongkolan vertikal). Hal ini sangat disayangkan karena perilaku tersebut sangat merugikan kepentingan umum demi mengejar keuntungan sekelompok orang. Dalam berbagai perkara yang memiliki indikasi korupsi, KPPU memberikan rekomendasi untuk ditangani secara pidana oleh pihak yang berwenang dan telah ditindaklanjuti dengan baik.

Pada Undang-Undang No. 5 tahun 1999 tentang Larangan Praktek Monopoli dan Persaingan Usaha Tidak sehat ini, ada 3 pasal yang mengatur tentang persekongkolan yaitu Pasal 22, Pasal 23, dan Pasal 24. Dari ketiga pasal di atas, dapat dikatakan bahwa kegiatan persekongkolan yang dilarang dapat dibagi dalam 3 (tiga) kategori, yaitu persekongkolan yang berkaitan dengan tender yang mencakup pengaturan atau penentuan pemegang tender yang tidak wajar; persekongkolan yang berkaitan dengan informasi atau rahasia perusahaan; dan persekongkolan yang berkaitan dengan upaya menghambat produksi dan/atau pemasaran barang dan/atau jasa secara ilegal (Hermansyah, 2009).

Dalam praktek, persekongkolan demikian ditengarai banyak terjadi di Indonesia. Tercatat bahwa sejak dibentuknya Komisi Pengawas Peraingan Usaha (KPPU) sudah menerima 376 laporan mengenai persekongkolan tender. Dari sekian banyak laporan tersebut baru 54 laporan yang ditangani. Dengan demikian hampir dua per tiga dari kasus yang masuk ke KPPU adalah kasus persekongkolan tender.

Dalam pasal 30 - 37 Undang-undang Nomor 5 Tahun 1999 dengan tegas diamanatkan berdirinya suatu komisi yang independen yang disebut dengan Komisi Pengawas Persaingan Usaha (KPPU). KPPU berdasarkan Keputusan Presiden Republik Indonesia Nomor 75 Tahun 1999. Adapun dasar hukum pembentukan Komisi pengawas adalah Pasal 30 ayat (1), yang menyatakan bahwa:

...Untuk mengawasi pelaksanaan undang-undang ini dibentuk Komisi Pengawas Persaingan Usaha ...

Komisi Pengawas Persaingan Usaha (KPPU) adalah suatu lembaga yang khusus dibentuk oleh dan berdasarkan Undang-undang untuk mengawasi jalannya Undang-undang. KPPU merupakan lembaga independen yang terlepas dari pengaruh dan kekuasaan pemerintah sertapihak lainnya. KPPU bertanggung jawab langsung kepada presiden, selaku Kepala Negara (Ahmad Yani, 2002).

Selanjutnya pasal 1 Angka 18 Keppres Nomor 75 Tahun 1999 ini menyatakan pula bahwa:

... Komisi Pengawas Persaingan Usaha adalah komisi yang dibentuk untuk mengawasi pelaku usaha dalam menjalankan kegiatan usahanya agar tidak melakukan praktek monopoli dan atau persaingan usaha tidak sehat ... 
KPPU adalah lembaga yang tepat untuk menyelesaikan persoalan persaingan usaha yang mempunya peran multifunction dan keahlian sehingga dianggap mampu menyelesaikan dan mempercepat proses penanganan perkara (Ma'rif, 2002). Maka dari itu KPPU berhak menangani perkara yang berkaitan dengan persekongkolan tender. Persekongkolan tender (collusive tendering atau bid rigging) dapat mengakibatkan persaingan yang tidak sehat. Selain itu, ia dapat merugikan panitia pelaksana tender dan pihak peserta tender yang beriktikad baik. Karena itu, tender sering menjadi perbuatan atau kegiatan yang dapat mengakibatkan adanya persaingan usaha tidak sehat. Persaingan usaha tidak sehat pada persekongkolan tender disebabkan oleh ketidakseimbangan antara pasar dengan jumlah pelaku usaha (Sukino, 2003).

Pada hakekatnya, pelaksanaan tender wajib memenuhi asas keadilan, keterbukaan, dan tidak diskriminatif. Selain itu, tender harus memperhatikan halhal yang tidak bertentangan dengan asas persaingan usaha yang sehat.

Pertama: tender tidak bersifat diskriminatif, dapat dipenuhi oleh semua calon peserta-tender dengan kompetensi yang sama.

Kedua: tender tidak diarahkan pada pelaku usaha tertentu dengan kualifikasi dan spesifikasi teknis tertentu.

Ketiga: tender tidak mempersyaratkan kualifikasi dan spesifikasi teknis produk tertentu.

Keempat: tender harus bersifat terbuka, transparan, dan diumumkan dalam media masa dalam jangka waktu yang cukup. Karena itu, tender harus dilakukan secara terbuka untuk umum dengan pengumuman secara luas melalui media cetak dan papan pengumuman resmi untuk penerangan umum dan bilamana dimungkinkan melalui media elektronik, sehingga masyarakat luas dunia usaha yang berminat dan memenuhi kualifikasi dapat mengikutinya.

Tender dalam hukum persaingan usaha Indonesia mempunyai pengertian tawaran mengajukan harga untuk memborong suatu pekerjaan, untuk mengadakan barang-barang atau untuk menyediakan jasa. Tawaran dilakukan oleh pemilik kegiatan atau proyek. Demi alasan efektivitas dan efisiensi proyek dilaksanakan sendiri maka lebih baik diserahkan kepada pihak lain yang mempunyai kapabilitas melaksanakan proyek atau kegiatan.

Dalam praktiknya, pengertian tender sama dengan pengertian lelang. Pelelangan umum adalah metode pemilihan penyedia barang/jasa yang dilakukan secara terbuka dengan pengumuman secara luas melalui media massa dan papan pengumuman resmi untuk penerangan umum sehingga masyarakat luas dan dunia usaha yang memenuhi kualifikasi dapat mengikuti lelang tersebut. Sedangkan pelelangan terbatas adalah metode pemilihan penyedia barang/jasa yang dilakukan secara terbuka dengan pengumuman resmi dengan mencantumkan penyedia barang/jasa yang telah diyakini mampu, guna memberi kesempatan kepada penyedia barang/jasa lainnya yang memenuhi kualifikasi (Lubis, 2009).

Seperti yang telah dijelaskan sebelumnya, dalam Undang-Undang Nomor 5 Tahun 1999 pasal 1 angka 8, yang dimaksud dengan persekongkolan adalah: 
... Persekongkolan atau konspirasi usaha adalah bentuk kerja sama yang dilakukan oleh pelaku usaha dengan pelaku usaha lain dengan maksud untuk menguasai pasar bersangkutan bagi kepentingan pelaku usaha yang bersekongkol ...

Bentuk kegiatan persekongkolan tidak harus dibuktikan dengan adanya perjanjian, akan tetapi bisa dalam bentuk kegiatan lainnya yang tidak mungkin diwujudkan dalam suatu perjanjian (Usman, 2013). Dengan demikian, jika pada perjanjian untuk memonopoli atau menyaingi secara curang yang ditekankan adalah perjanjian tersebut, sementara dalam persekongkolan belum tentu ada perjanjian. Bahkan dalam banyak kasus dalam praktek, perjanjian tersebut sama sekali tidak dibuat, karena memang materinya sangat tidak tepat untuk dimuat dalam suatu perjanjian (Fuady, 1999).

Pelaku usaha tidak dapat melakukan kesepakatan dengan pihak lain yang terkait secara langsung atau tidak langsung dengan memberi proyek, penyelenggara tender, dan/atau diantara mereka sendiri untuk mengatur dan/atau menentukan pemenang tender. Hal ini disebabkan oleh karena praktik usaha ini dapat menimbulkan praktik monopoli dan persaingan usaha tidak sehat. Praktik usaha tidak sehat ini dapat menyebabkan terjadinya penggelembungan harga (mark-up) yang memberikan keuntungan berlebihan kepada pemenang tender dan mengakibatkan inefisiensi yang merugikan negara dan masyarakat luas. Jika ada pelaku usaha dan/atau kelompok usaha yang melakukan praktik persekongkolan tersebut, berarti mereka telaah melakukan praktik usaha yang dilarang menurut ketentuan undang-undang nomor 5 tahun 1999 (Margono, 1999).

Selanjutnya, menurut Margono (1999), persekongkolan terjadi apabila pelaku usaha:

1) Memperoleh dan menggunakan fasilitas ekslusif dari pihak yang terkait secara langsung maupun tak langsung dengan pemberi proyek dan/atau penyelenggara tender sehingga dapat menyusun penawaran yang lebih baik.

2) Membuat kesepakatan dengan pihak yang terkait secara langsung mauapun tak langsung dengan pemberi proyek, penyelenggara tender, dan/atau diantara mereka untuk menentukan pemenang secara bergilir pada serangkaian tender.

3) Membuat kesepakatan dengan pihak yang terkait secara langsung maupun tak langsung dengan pemberi proyek, penyelenggara tender, dan/atau diantara mereka untuk menentukan pemenang secara bergilir pada serangkaian tender.

4) Membuat kesepakatan dengan pihak yang terkait secara langsung maupun tak langsung dengan pemberi proyek, penyelenggara tender, dan/atau diantara mereka untuk menentukan pemenang, baik untuk akan secara bersama maupun dengan kompensasi tertentu.

5) Menggunakan kesempatan ekslusif melakukan penawaran tender sebelum waktu yang di tetapkan.

Fasilitas ekslusif yang diberikan penyelenggara tender dan/atau pihak terkait dapat berupa informasi tertentu (Margono, 1999), misalnya tentang:

1) Nilai proyek dan/atau struktur penawaran pelaku usaha lain;

2) Informasi dini yang diberikan jauh sebelum disampaikan kepada pelaku usaha lain;

3) Peraturan tertentu yang menjadi hambatan bagi pelaku usaha lain; 
4) Penetapan pemenang yang direkayasa peserta tender yang lain hanya diperlakukan sebagai pembanding dan sebelumnya sudah dipastikan kalah dan sebagainya.

Tugas dan wewenag KPPU, telah dijabarkan dengan sangat jelas dan seksama dalam peraturan perundang-undangan, maka pembahasan selanjutnya mengenai sifat dan bentuk putusan KPPU, pengambilan putusan yang dilakukan KPPU diatur di dalam pasal 43 ayat 3 Undang-Undang Nomor 5tahun1999 yang mengatakan bahwa:

\section{Pasal 43}

1. Komisi wajib menyelesaikan pemeriksaan lanjutan selambat-lambatnya 60 (enam puluh) hari sejak dilakukan pemeriksaan lanjutan sebagaimana dimaksud dalam Pasal 39 ayat (1).

2. Bilamana diperlukan, jangka waktu pemeriksaan lanjutan sebagaimana dimaksud dalam ayat (1) dapat diperpanjang paling lama 30 (tiga puluh) hari.

3. Komisi wajib memutuskan telah terjadi atau tidak terjadi pelanggaran terhadap Undang-undang ini selambat-lambatnya 30 (tiga puluh) hari terhitung sejak selesainya pemeriksaan lanjutan sebagaimana dimaksud dalam ayat (1) atau ayat (2).

4. Putusan Komisi sebagaimana dimaksud dalam ayat (3) harus dibacakan dalam suatu sidang yang dinyatakan terbuka untuk umum dan segera diberitahukan kepada pelaku usaha.

Dalam kutipan pasal di atas telah dijelaskan bahwa komisi wajib memutuskan telah terjadi atau tidak terjadinya pelanggaran terhadap undang-undang selambatlambatnya 30 dari terhitung sejak selesainya pemeriksaan lanjutan (ayat 3). Di dalam kutipan pasal di atas juga dijelaskan bahwa pengambilan keputusan KPPU sebagaimana dimaksud dilakukan dalam bidang suatu majelis yang beranggotakan sekurangnya 3 orang anggota komisi. Hal ini juga di perjelas dalam Keppes Nomor 75 tahun 1999, yang mengatakan bahwa:

\section{Pasal 7}

1. Untuk menyelesaikan suatu perkara, Komisi melakukan sidang majelis.

2. Pengambilan keputusan Komisi dilakukan dalam sidang majelis sebagaimana dimaksud pada ayat (1) yang beranggotakan sekurangkurangnya 3 (tiga) orang Komisi.

3. Keputusan Komisi sebagaimana dimaksud pada ayat (2) ditandatangani oleh seluruh anggota majelis.

Atas dasar putusan KPPU yang menyatakan suatu perkara tersebut terbukti adanya pelanggaran terhadap ketentuan peraturan perundang-undangan yakni Undang-Undang Nomor 5 tahun 1999 tentang Larangan Praktik Monopoli Dan Persaingan Usaha Tidak Sehat, maka sesuai dengan tugas dan kewenangannya KPPU dapat memutus dan menjatuhkan sanksi administratif dalam putusannya. Undang-Undang Nomor 5 tahun 1999 tentang Larangan Praktek Monopoli Dan Persaingan Usaha Tidak Sehat juga memberikan kesepatan bagi pihak yang merasa dirugikan terhadap putusan KPPUuntuk mengajukan upaya hukum keberatan, 
namun jika tidak maka keputusan KPPU tersebu berkekuatan hukum tetap atau Inkraht Van Geweijde.

\section{Eksistensi KPPU dalam Menyelesaiakan Masalah Terkait Persekongkolan Tender Dilihat dari Perspektif Hukum Positif Indonesia.}

Pasca terjadinya krisis moneter pada tahun 1998, pemerintah mengeluarkan UU No 5 Tahun 1999 tentang Larangan Praktik Monopoli dan Persaingan Usaha Tidak Sehat (UU Anti Monopoli). Kemudian berselang satu tahun kemudian yakni tahun 2000, lembaga Komisi Pengawas Persaingan Usaha (KPPU) resmi dibentuk (Sumber: https://www.hukumonline.com/berita/baca/lt592e75913b6c7/ini-catatankinerja-kppu-selama-17-tahun). Komisi Pengawas Persaingan Usaha (KPPU) yang dibentuk berdasarkan Undang-Undang Nomor 5 Tahun 1999 memiliki peran sebagai lembaga penegakan hukum dan advokasi persaingan usaha. KPPU mendukung program kebijakan pemerintah untuk mewujudkan pembangunan berkelanjutan serta mewujudkan pertumbuhan ekonomi yang inklusif dengan mendorong kemandirian ekonomi, berkelanjutan sosial dan kesejahteraan masyarakat serta mengurangi kesenjangan antar wilayah dengan mengawal kebijakan dan strategi ekonomi rakyat yang berkelanjutan.

Berdasarkan perkembangan perekonomian nasional di Indonesia selama kurang lebih 3 (tiga) dasawarsa sebelum tahun 1999 menunjukkan bahwa kebijakan yang diterapkan di bidang perekonomian kurang mengacu kepada amanat pasal 33 Undang-Undang Dasar 1945, bahkan cenderung menunjukkan corak yang sangat monopolistik. Keadaan tersebut antara lain adalah para pelaku usaha yang dekat dengan para elit-elit pemerintahan, sehingga mereka lebih mendapat kemudahan dan menciptakan kesenjangan sosial (Wafiya, 2014).

Pelanggaran dalam persaingan usaha sudah banyak terjadi di Indonesia, tepatnya pada persekongkolan tender. Hampir sekitar $80 \%$ pelanggaran yang diterima KPPU adalah mengenai persekongkolan tender tepatnya pada pengadaan barang dan jasa. Semenjak KPPU berdiri, KPPU telah menerima lebih kurang sebanyak 2094 laporan yang terdiri dari laporan perkara dan dugaan pelanggaran persaingan usaha (Sumber: Detik News. https://news.detik.com/berita/d3371375/kppu--80-persen-persekongkolan-tenderterkait- pengadaan-barang-danjasa).

Pada tahun 2016, KPPU mulai menjalankan amanat Undang-Undang Nomor 20 Tahun 2008 tentang Usaha Mikro, Kecil dan Menengah serta PP Nomor 17 Tahun 2013 tentang Pelaksanaan UU Nomor 20 Tahun 2008 untuk melakukan pengawasan kemitraan sebagai upaya yang ditempuh atas kondisi pemberdayaan ekonomi rakyat yang dirasa belum mendapatkan kesempatan yang sama dalam pengembangan usaha (Sumber: Komisi pengawas persaingan usaha, laporan kinerja KPPU 2016).

Ketua KPPU Syarkawi Rauf mengatakan, selama 16 tahun KPPU berdiri (2000-2016), KPPU sudah menerima laporan sebanyak 2.537 laporan adanya dugaan pelanggaran UU Anti Monopoli dengan komposisi yang didominasi oleh laporan terkait pengadaan barang dan jasa (tender) sebanyak 73 persen. Sedangkan total denda dan ganti rugi yang bervariasi dan terbagi atas Denda bersyarat, denda 
administratif dan ganti rugi (Sumber: https://www.hukumonline.com/berita/ baca/lt592e75913b6c7/ini-catatan-kinerja-kppu-selama-17-tahun).

Tugas dan fungsi KPPU juga sejalan dengan arah kebijakan pengembangan penghidupan berkelanjutan dengan peningkatan akses terhadap kegiatan ekonomi yang produktif dan berdaya saing. Berdasarkan RPJMN 2015-2019, daya saing Indonesia masih dipandang rendah. Hal ini, terlihat dari masih banyaknya praktikpraktik kegiatan ekonomi yang terindikasi inefisien dengan adanya praktik persaingan usaha yang tidak sehat karena masih kurangnya pemahaman nilai-nilai persaingan usaha di lingkungan pelaku usaha.

Oleh karena itu, sebagai lembaga pengawas, KPPU menjalankan tugas pengawasan untuk mendorong peningkatan kesadaran dan perubahan perilaku pelaku usaha dengan mengimplemantasikan kebijakan persaingan usaha oleh pengambil kebijakan serta peningkatan perekonomian berupa peningkatan kesejahteraan rakyat.

Salah satu tugas utama KPPU adalah melakukan penegakan hukum persaingan usaha. Terkait hal tersebut, patut disyukuri bahwa keberadaan KPPU telah menjadi sebuah bagian yang tidak terpisahkan dari legal framework Indonesia sehingga bisa menjadi sandaran kepastian hukum bagi para pencari keadilan dalam kasus persaingan usaha.

Sejak tahun 2000-2016, KPPU telah menyelesaikan 342 total perkara dengan 245 diantaranya adalah perkara tender. Dengan capaian perkara yang bersumber dari laporan sebanyak 288 perkara dan yang berdasarkan inisiatif KPPU sebanyak 54 perkara. Selanjutnya terdapat 9 perkara terkait keterlambatan notifikasi merger. Total nilai tender yang telah diperiksa KPPU adalah senilai Rp. 33,1 Trilyun dan USD 142,5 Milyar.

KPPU merupakan lembaga independen yang terlepas dari pengaruh kekuasaan pemerintah dan pihak lain dan bertanggung jawab kepada Presiden selaku kepala negara. Dalam mencapai kemandirian ekonomi, terdapat 4 (empat) pilar arah kebijakan dan strategi yang mempunyai peran strategis, meliputi:

1) ekonomi rakyat yang berkelanjutan;

2) daya saing bangsa;

3) kedaulatan pangan dan energy, dan

4) posisi negara maritime (http://www.kppu.go.id/docs/LaporanKeuangan/

Renstra\%20KPPU\%202015-2019.pdf).

Berdasarkan Undang-Undang Nomor 5 tahun 1999 tentang Larangan Praktik Monopoli dan Persaingan Usaha Tidak Sehat, para pendahulu telah meletakkan landasan dalam menerapkan prinsip-prinsip persaingan usaha yang sehat bagi pelaku usaha yang berdomisili di Indonesia. Adapun tujuan Undang-Undang No. 5 Tahun 1999 ini sebagaimana tercantum dalam pasal 3, yaitu:

1) Menjaga kepentingan umum dan meningkatkan efisiensi ekonomi nasional sebagai salah satu upaya untuk meningkatkan kesejahteraan rakyat.

2) Mewujudkan iklim usaha yang kondusif melalui pengaturan persaingan usaha yang sehat sehingga menjamin adanya kepastian kesempatan berusaha yang sama bagi pelaku usaha besar, pelaku usaha menengah, dan pelaku usaha kecil.

3) Mencegah praktik monopoli dan atau persaingan usaha tidak sehat yang ditimbulkan oleh pelaku usaha; dan 
4) Terciptanya efektivitas dan efisiensi dalam kegiatan usaha.

Tema pembangunan 2018 yang menekankan pada investasi dan percepatan pembangunan infrastruktur ini diharapkan dapat menjadi pendorong pertumbuhan ekonomi di tahun 2018 mendatang serta sekaligus mengurangi ketimpangan yang ada baik antar individu maupun antar wilayah. Dalam Rencana Kerja Pemerintah Tahun 2018 telah disepakati 10 Prioritas Nasional yang meliputi:

(1) Pendidikan;

(2) Kesehatan;

(3) Perumahan dan Permukiman;

(4) Pengembangan Dunia Usaha dan Pariwisata;

(5) Ketahanan Energi;

(6) Ketahanan Pangan;

(7) Penanggulangan Kemiskinan;

(8) Infrastruktur, Konektivitas, dan Kemaritiman;

(9) Pembangunan Wilayah;

(10) Politik, Hukum, Pertahanan, dan Kemanan

Sejumlah perkara yang ditangani oleh KPPU saat ini ternyata masih seputar permasalahan di sektor infrastruktur misalnya dalam penyelenggaraan tender. Hal ini dipaparkan dalam salah satu capaian kinerja dalam bidang penegakan hukum. Selanjutnya, pada Laporan Kinerja KPPU tahun 2017 dapat dicermati apresiasi terhadap keberadaan KPPU sebagai lembaga pengawas yang aktif melakukan internalisasi nilai-nilai persaingan usaha yang sehat di kalangan pelaku usaha, pemerintah dan masyarakat, meningkatkan kepastian penegakan hukum persaingan usaha untuk menjamin iklim investasi dan iklim usaha yang sehat yang pada akhirnya juga meningkatkan kredibilitas dan akuntabilitas kelembagaan KPPU.

Berdasarkan Surat Keputusan Deputi Penegakan Hukum Komisi Pengawas Persaingan Usaha dibentuk Satuan TugasPenelitian Dugaan Pelanggaran yang ditentukan oleh rapat koordinasi dan atau rapat komisioner.Tim Perkara Inisiatif memiliki target sebanyak 31 (tiga puluh satu) laporan hasil penelitian yang dilakukan pada tahun 2017. Per Desember 2017, Unit Perkara Inisiatif telah melakukan 31 (tiga puluh satu) penelitian dan 3 (tiga) kegiatan pengawasan langsung (inspeksi) sektor pangan dan UMKM, Penelitian Perkara Inisiatif tahun 2017 terdiri dari 20 (dua puluh) terkait pengadaan/lelang dan 10 (sepuluh) terkait non tender, dengan matriks sebagai berikut:

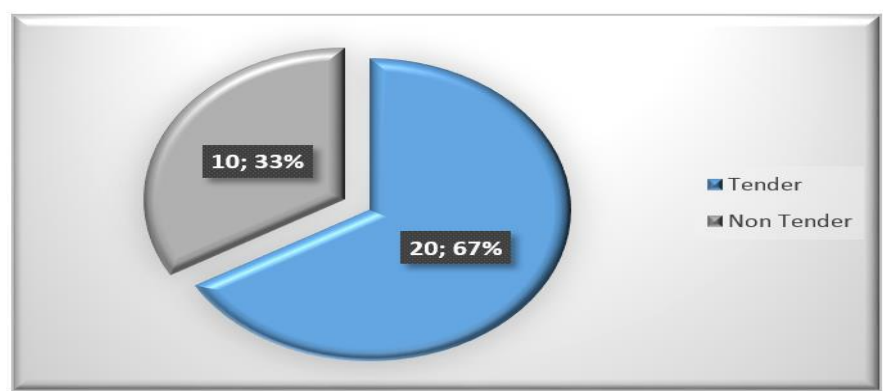

Gambar 1. Jumlah Laporan yang Diterima KPPU Periode Tahun 2010 - 2017 
Dari hasil presentase hasil penelitian/laporan klarifikasi yang ditindaklanjuti di tahap penyelidikan dengan target 12\%, maka di dapat bahwa capaian tahun 2017 adalah 15,3 \%, melebihi target yang ditetapkan sebelumnya di tahun 2017. Walaupun demikian dalam kegiatan klarifikasi dan penelitian perkara insiatif ini masih terdapat kekurangan, diantaranya yaitu:

1. Banyaknya laporan dari pelapor yang tidak dapat memenuhi ketentuan sebagaimana ditetapkan dalam pasal 11 ayat 3 Perkom 1 Tahun 2010, yaitu pelapor harus melengkapi:

a. Menyertakan secara lengkap identitas pelapor, terlapor, dan saksi;

b. Menerangkan secara jelas sedapat mungkin lengkap dan cermat mengenai telah terjadinya pelanggaran terhadap undang - undang

c. Menyampaikan alat bukti dugaan pelanggaran

d. Menyampaikan salinan identitas diri pelapor

e. Menandatangani laporan

2. Banyaknya laporan dari masyarakat bukan merupakan kewenangan absolut KPPU. Presentase laporan hasil penyelidikan yang ditindaklanjuti ke tahap Persidangan Majelis pada tahun 2017 dapat terlaksana dengan adanya dukungan dari sasaran kegiatan, yang diukur melalui indikator kinerja kegiatan tahun 2017 sebagai berikut:

Tabel 1. Presentase laporan hasil penyelidikan yang ditindaklanjuti ke tahap Persidangan Majelis pada tahun 2017

\begin{tabular}{|llccc|}
\hline No & \multicolumn{1}{c}{ Indikator Kinerja Kegiatan } & Target & Capaian & $\%$ \\
\hline 1 & $\begin{array}{l}\text { Penyelidikan pelanggaran Persaingan } \\
\text { Usaha }\end{array}$ & 70 & 67 & $95.71 \%$ \\
\hline
\end{tabular}

Terkait dengan hasil penyelidikan pada tahun 2017, maka pada periode tersebut telah dilakukan penyelidikan sebesar 67 kali penyelidikan. Adapun tabel penjelasan kegiatan penyelidikan adalah sebagai berikut:

Tabel 2. Hasil penyelidikan yang ditindaklanjuti ke tahap Persidangan Majelis pada tahun 2017

\begin{tabular}{|llc|}
\hline No & \multicolumn{1}{c}{ Kegiolon } & Total \\
\hline 1 & Penyelidikan tahun sebelumnya & 8 \\
\hline 2 & Penyelidikan register tahun 2017 & 48 \\
\hline 3 & Penyelidikan kembali dari pemberkasan & 11 \\
\hline Total penyelidikan & 67 \\
\hline
\end{tabular}

Berdasarkan Tabel 2 di atas terdapat perbedaan perhitungan antara bagian penyelidikan dengan bagian pembekasan, dimana pada akhir tahun unit pemberkasan telah mengembalikan satu berkas laporan hasil penyelidikan yang 
menambah input unit penyelidikan; sehingga total 67 kegiatan penyelidikan, dilaksanakan sampai dengan akhir tahun 2017 terlihat posisi laporan penyelidikan adalah sebagai berikut:

\section{Tabel 3. Hasil penyelidikan berdasarkan Kegiatan tahun 2017}

\begin{tabular}{|c|c|c|}
\hline Ma & Regiafor & Tohal \\
\hline 1 & Tender & 57 \\
\hline 2 & Hon Tenaler & 50 \\
\hline \multicolumn{2}{|c|}{ Tolal Femyelidikan } & $\Delta 7$ \\
\hline
\end{tabular}

\begin{tabular}{|ccc|} 
No Asal kegiaton & Tolal \\
\hline $\mathbf{1}$ & Klarifikasi Laporan & 30 \\
\hline $\mathbf{2}$ & Penelitian Perkara Inisiatif & 29 \\
\hline $\mathbf{3}$ & Merger dan akuisisi & 7 \\
\hline $\mathbf{4}$ & Kemitraan & 1 \\
\hline & Total Penyelidikan & 67 \\
\hline
\end{tabular}

\begin{tabular}{|c|c|c|c|c|}
\hline \multirow[b]{2}{*}{ No } & \multirow[b]{2}{*}{ Kegiatan } & \multirow[b]{2}{*}{ Total } & \multicolumn{2}{|c|}{ stalus Kinerja } \\
\hline & & & & Realisasi \\
\hline 1 & Penyeidikan yang berianjut ke pemberkasan & 21 & \multirow{4}{*}{$26 \%$} & \multirow{4}{*}{$31,34 \%$} \\
\hline 2 & Berhenti & 17 & & \\
\hline 3 & Berhenti dengan rekomendasi & 2 & & \\
\hline 4 & Penyelidkan sedang berjalan & 27 & & \\
\hline Tota & Penyelidikan & 67 & Terc & apdi \\
\hline
\end{tabular}

Adapun persentase kegiatan penanganan perkara akan dijelaskan sebagai berikut:

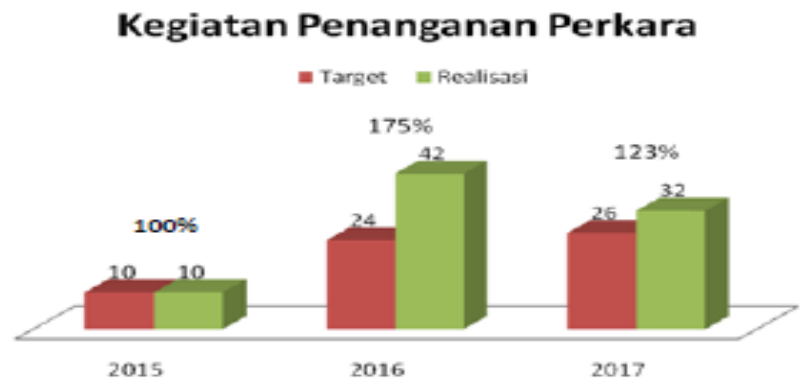

1) Terjadinya lonjakan target penanganan perkara dari tahun 2015 ke tahun 2016 , dari 10 target menjadi 24 target penanganan perkara; 
2) Namun dari target 24 output di tahun 2016 dimaksud, terdapat realisasi sebesar 175\% kegiatan pepnanganan perkara yang terealisasi di tahun 2016

3) Peningkatan dimaksud menyebabkan kegiatan investigator banyak tersita untuk menyelesaikan penanganan perkara yang berjalan dari tahun 2016, sehingga membutuhkan waktu yang lama untuk menyelesaikan penyelidikan di tahun 2016, dikarenakan investigator penyelidik bertindak juga sebagai investigator penuntut, yang disebabkan oleh kurangnya sumber daya manusia (sdm) dalam penanganan perkara ini.

Dari berbagai uraian di atas penulis mencoba mengambil suatu kasus yang telah di putus oleh KPPU, terkait dengan persekongkolan tender, yaitu: Putusan tentang Persekongkolan Tender (Putusan KPPU No. 01/KPPU-L/2000). Dalam Putusan KPPU No.01/KPPU-L/2000 ini, pasal yang dilanggar adalah pasal $22 \mathrm{UU}$ No. 5 Tahun 1999 tentang Monopoli dan Persaingan Usaha Tidak Sehat. Persekongkolan tender ini berawal dari adanya laporan dari salah satu pelapor yang merupakan salah satu anggota tender dalam rangka pengadaan casing dan tubing, yang melaporkan bahwa terlapor memberlakukan persyaratan baru dalam penawaran tender yaitu sistem penawaran satu paket dengan menggabungkan lowgrade dengan high-grade.

Dalam hal ini terlapor sudah terlebih dahulu mengetahui bahwa pelaku usaha yang dapat memenuhi persyaratan tersebut hanyalah PT. Citra Tubindo Tbk dan PT. Seamless Pipe Indonesia Jaya. Selain itu terlapor juga mensyaratkan bahwa peserta tender yang hanya memiliki fasilitas low grade diharuskan menyerahkan surat dukungan (letter of support) kepada pelaku usaha dalam negeri (Surat Direktur Pembinaan Pengusahan Migas, Ditjen Minyak dan Gas Bumi Departemen Pertambangan dan Energi RI No. 005/396/DMB/1992 perihal Penggunaan Fasilitas Heat Treatment dan Threading di Dalam Negeri) yang memiliki fasilitas high-grade.

Oleh karena adanya persyaratan tersebut, PT. Purna Bina Nusa dan PT. Patraindo Nusa Pertiwi meminta dukungan dari PT. Citra Tubindo, Tbk, dengan dilakukannya pertemuan satu hari menjelang dibukanya tender. Surat dukungan tersebut diberikan setelah Citra Tubindo meminta PT. Purna Bina Nusa dan Patraindo Nusa Pertiwi memperlihatkan harga penawaran karena dijanjikan akan mendapatkan pekerjaan dari Citra Tubindo. Sehingga pada saat pembukaan tender, Citra Tubindo memberikan harga penawaran terendah dari pada para peserta tender yang lain, sehingga Citra Tubindo memenangkan tender tersebut.

Berdasarkan alasan-alasan tersebut, KPPU menyimpulkan bahwa dalam pembukaan tender yang diselenggarakan oleh terlapor, telah terjadi persekongkolan antara Citra Tubindo dengan PT. Purna Bina Nusa dan PT. Patraindo Nusa Pertiwi untuk mengatur dan atau menentukan pemenang tender sehingga menyebabkan persaingan usaha tidak sehat, dan dinyatakan melanggar ketentuan Pasal 22 UU No5 Tahun 1999. Sedangkan terlapor hanya dianggap kurang hati-hati dalam menjaga suasana persaingan agar tetap sehat, dan kepada tindakan terlapor dinyatakan sebagai pengecualian dalam persaingan usaha tidak sehat sebagaimana diatur dalam Pasal 50 huruf a UU No.5 Tahun 1999 karena adanya Surat Direktur Pembinaan Pengusahan Migas, Dirjen Minyak dan Gas Bumi Departemen Pertambangan dan Energi RI No.005/396/DMB/1992 perihal Penggunaan Fasilitas Heat Treatment dan Threading 
di Dalam Negeri, dan memerintahkan kepada terlapor untuk menghentikan kegiatan pengadaan casing dan tubing berdasarkan tender.

Dalam Putusan KPPU No.01/KPPU-L/2000 ini, terlihat bahwa persekongkolan tender menjadi sangat mungkin terjadi disebabkan adanya peraturan peraturan perundangan yang berlaku. Dalam hal ini adalah adanya Surat Direktur Pembinaan Pengusahan Migas, Dirjen Minyak dan Gas Bumi Departemen Pertambangan dan Energi RI No.005/396/DMB/1992 perihal Penggunaan Fasilitas Heat Treatment dan Threading di Dalam Negeri, dan persekongkolan mungkin terjadi antar peserta tender, dimana para peserta tender membuat kesepakatan bahwa salah satu peserta tender akan mendapatkan pekerjaan dari peserta tender lain yang telah diatur dan ditentukan untuk memenangkan tender tersebut jika mengajukan penawaran harga yang lebih tinggi dari peserta yang telah ditentukan memenangkan tender.

\section{Kesimpulan}

Persekongkolan tender yang diawasi oleh KPPU terbukti marak terjadi. Untuk itu KPPU dalam menjalankan tugasnya dijalankan berdasarkan kedudukan Komisi Pengawas Persaingan Usaha (KPPU). Dalam sistem peradilan KPPU merupakan lembaga yang dapat memutus suatu sengketa terkait persaingan usaha yang tidak sehat, yang bersifat independen terlepas dari pengaruh-pengaruh lembaga lain. KPPU juga bukan merupakan lembaga di bawah yuridiksi Mahkamah Agung. KPPU merupakan lembaga yang mandiri yang bertanggung jawab terhadap presiden. Hasil putusan KPPU dalam memutus perkara juga bersifat inkrach van gewisde, selama tidak diajukan upaya hukum keberatan kepada Pengadilan Negeri (PN) setempat.

Eksistensi dan peran komisi pengawas persaingan usaha (KPPU) dalam menyelesaikan masalah persaingan usaha tidak sehat khususnya persekongkolan tender banyak sekali terlihat dan terjadi terutama dalam bidang pengadaan barang dan jasa yang menggunakan sistem tender atau lelang dalam pelaksanaannya. Penyelesaian terkait masalah ini tentunya dimulai dengan pemeriksaan atas adanya laporan sesuai dengan keputusan KPPU Nomor 5 tahun 2000 tentang tata cara penyampaian laporan dan penanganan dugaan terhadap Undang-Undang Nomor 5 tahun 1999 tentang persaingan usaha tidak sehat. Kemudian dilanjutkan dengan tahapan lanjutan sesuai dengan pasal 39 ayat (2) Undang-Undang Nomor 5 tahun 1999.

Selain itu dapat pula disimpulkan bahwa KPPU dalam menyelesaikan perkara terkait persekongkolan tender selama ini telah sesuai dengan peraturan perundangundangan yang berlaku dengan memperoleh hasil yang baik. Hal ini dibuktikan sebagaimana peneliti telah uraikan dan tercantum dalam laporan kinerja KPPU setiap tahunnya.

\section{DAFTAR KEPUSTAKAAN}

Ahmad Yani, Gunawan Widjaja. (2002). Anti Monopoli Seri Hukum Bisnis. Jakarta: Raja Grafindo Persada. 
Fuady, Munir (1999). Hukum Persaingan Usaha: Menyongsong Era Persaingan Sehat. Cetakan Pertama. Bandung: PT. Citra Aditya Bakti.

Hermansyah. (2009). Pokok-Pokok Hukum Persaingan Usaha di Indonesia. Jakarta: Kencana.

Komisi Pengawas Persaingan Usaha (KPPU). (2016). Laporan kinerja KPPU 2016.

Komisi Pengawas Persaingan Usaha (KPPU). (2017). Laporan kinerja KPPU 2017.

Krisanto, Yakub Adi. (2008). Terobosan Hukum Putusan KPPU dalam Mengembangkan Penafsiran Hukum Persekongkolan Tender (Analisis Putusan KPPU Terhadap Pasal 22 Uu Nomor 5 Tahun 1999 Pasca Tahun 2006). Jurnal Hukum Bisnis. Volume 27 Nomor 3, 2008.

Lubis, Andi Fahmi, et.al. (2009). Hukum Persaingan Usaha Antara Teks \& Konteks. Jakarta: ROV Creative Media.

Ma'rif, Syamsul. (2002). Tantangan Penegakan Hukum Persaingan Usaha di Indonesia. Jurnal Hukum Bisnis. Vol. 19 Mei-Juni, 2002.

Margono, Suyud. (2009). Hukum Anti Monopoli. Jakarta: Sinar Grafika.

Peraturan KPPU Nomor 2 tahun 2010 tentang

Saliman, Abdul R. (2004). Esensi Hukum Bisnis Indonesia Teori dan Contoh Kasus. Jakarta: Kencana.

Sukino, Sadono. (2003). Hukum Anti Monopoli: Menyongsong Era Persaingan Sehat. cet.II. Bandung: PT. Citra Aditya Bakti.

Usman, Rachmadi. (2013). Hukum Persaingan Usaha di Indonesia. Jakarta: Sinar Grafika.

Wafiya (2014). Politik Hukum Pembentukan Undang-undang Larangan Praktek Monopoli dan Persaingan Usaha Tidak Sehat. Fiat Justisia Jurnal Ilmu Hukum. Volume 8 No.4, Oktober - Desember 2014.

\section{Sumber Internet/Online:}

https://www.hukumonline.com/berita/baca/lt592e75913b6c7/ini-catatan-kinerjakppu-selama-17-tahun/, diakses pada tangal 21 agustus 2019, pukul 13.00 wita.

http://www.kppu.go.id/docs/LaporanKeuangan/Renstra\%20KPPU\%2020152019.pdf, diakses pada tanggal 27 agustus 2019, pukul 23.00 wita.

Detik News, "KPPU: 80 Persen Persekongkolan Tender Terkait Pengadaan Barang dan Jasa", di akses dari https://news.detik.com/berita/d-3371375/kppu--80persen-persekongkolan-tenderterkait- pengadaan-barang-dan-jasa, pada tanggal 21 agustus 2019. 